\title{
Journal Collection Analysis at a Liberal Arts College
}

\section{Steve Black}

\begin{abstract}
An inexpensive method for analyzing the cost-effectiveness of a liberal arts college's journal collection is described. The author offers an answer to the question: "What are the criteria for determining the cost-effectiveness of a journal collection, and how can the criteria be measured?" The resulting analysis is based on measurements of journal use, journal subscription prices, and course enrollment by academic department. Journal use data are also applied to shelf space management. Data collection methods are explained, and results of collection analysis are presented. The importance and benefits of empirical analysis of journal collections are discussed, and practical applications of the analysis are described.
\end{abstract}

$\mathbf{T}$ nals in an academic library is a complex, multifaceted process with budgetary, curricular, scholarly, and internal political implications. Given the persistently high annual inflation rate for journals, continual production of new journal titles, a neverending stream of requests from faculty for additions to collections, and tight budgetary environments, the presence of data on journal subscription prices, shelf space, and journal use can assist in making decisions. A serials librarian with data that have been carefully collected and analyzed can make or encourage better local collection development decisions and will be in a better position to defend those decisions. In this study, I examine how staff at the College of Saint Rose addressed the question, "What are the criteria for determining the cost-effectiveness of a journal collection, and how can the criteria be measured within an existing operating budget?" In this study, the author utilizes data collection techniques and methods of analysis that have not previously appeared in the library literature. A simple, inexpensive method of marking shelf labels was implemented for measuring use. The calculation of subscription cost divided by use is enhanced with data on the number of enrolled students served by each department's journal subscriptions.

\section{JoURNAL USE STUDIES}

The literature reviewed in the process of planning, executing, and reporting this journal collection analysis makes apparent the benefits of quantitative approaches to journal collection analysis and provides suggestions for conducting effective studies. Metz (1992) has written that measuring journal use is extremely useful and is an invaluable step prior to any serials cancellation project because of the peace of mind that use statistics give bibliographers. Although he recognizes the imperfection of use statistics, such statistics

STEVE BLACK (blacks@rosnet.strose.edu) is serials, reference, and instruction librarian, Neil Hellman Library, The College of Saint Rose, Albany, NY 12203. Manuscript received April 21, 1997; accepted for publication July 7, 1997. The author wishes to thank Paula Green, whose concientious work was essential to the study's success. 
at least indicate the titles that are used and reduce the chance of nominating a critical title for cancellation. Milne and Tiffany (1991) have described the economic advantages of calculating the cost-per-use of serials, which is defined as the current annual subscription price of a serial divided by the number of calculated uses per year. Using two factors, Milne and Tiffany adjusted counted journal uses to compensate for estimated undercounting and the number of years of issues surveyed. Bensman (1985) described the application of citation analysis to determine concentrations of use in journal collections and concluded that libraries should establish systems for monitoring use of their collections to identify low-use titles.

Broadus (1985b) described how one might use the citation statistics of ISI's Journal Citation Reports for collection analysis. Broadus proposed that citation analysis might supplement or even replace journal use studies. Eckman (1988) combined a use study, citation analysis, and list checking to analyze a specialized academic library's journal collection. The goal of his use study was to employ a simple method that would measure relative levels of use. Eckman's results aided collection development decisions and informed plans for future use studies. Young (1992) described a method of using bibliographic database transaction logs to assess a journals collection and concluded that logs of database transactions can provide an approximate measure of journal use. Gossen and Irving (1995) described how a journal use study conducted at the four State University of New York (SUNY) Centers (Albany, Binghamton, Buffalo, and Stony Brook) was used to investigate the benefits of canceling low-use titles and replacing the loss with interlibrary loan (ILL) and document delivery. Kingma (1996) more fully developed the work reported by Gossen and Irving by formalizing an economic model for determining the costs and benefits of owning journals versus obtaining articles by ILL or document delivery. Kingma's calculation of the cost-per-use of a journal includes the cost of shelf space, patrons' time, binding, and reshelving. Kingma also recognized, but chose not to include, the costs of photocopying, weeding, and vandalism in the calculation of cost-peruse. All these authors implemented or applied journal use studies in their analyses of journal collections.

Journal use study methods reported in the literature include several ways of counting volumes as they are reshelved, of counting users, and of monitoring circulation statistics. As noted by Herzog (Edelman 1994, 190), the most that can be expected from most use studies is a measure of relative use. No absolute measure of journal use is possible in open stacks. It is even difficult to define precisely what constitutes a use of a journal. For instance, is browsing a table of contents and choosing not to read any of the articles a use? Should uses by persons not affiliated with the college count? For a study that relies on a count of volumes found off the shelves (sometimes referred to as the "sweep" method), the definition of a use becomes "it was found on a table or cart." While this definition is simple and reasonable, its limits must be recognized, and results must be taken as best estimates rather than as absolutes.

However, alternatives to the sweep method, such as surveys that ask users what they have used or studies of bibliographies of papers created by library users, might not be more valid or reliable than reshelving counts. Naylor (1994) found fewer reported uses from a user survey than were recorded by reshelving counts. Analysis of bibliographies published by faculty and submitted in student papers as described by Joswick and Stierman (1997) is an interesting and valuable approach but produces a very small sample of a library's total journal use. Their method of counting citations printed from a bibliographic database is another possible approach, but it is unclear how printed citations reflect actual journal use. The method of checking references in student papers to evaluate a specific part of a collection was employed by Sylvia and Lesher (1995). They found, to their surprise, that shelving counts did not correspond to student citations.

As is frequently pointed out in the lit- 
erature, each method of journal analysis has its own strengths and weaknesses. The authors cited here have devised and employed methods of measuring journal use, calculating the cost efficiency of journals, and matching the resulting data to patron needs and economic exigencies. From these published methods of collection analysis, I adapted a method of counting journal use that best met local needs.

\section{Shelf Space Management}

An important aspect of the cost-effectiveness of a journal collection is the expense and availability of shelf space to house the journals. Sapp and Suttle (1994) point out that many libraries are running out of space and might not have the option of adding shelving or using remote storage. They report on a method of calculating collection expansion. Shelf space is also a component of the fixed cost of maintaining a subscription. Kingma (1996) determined the yearly fixed cost of shelf space at SUNY Albany to be $\$ 1.25$ per cubic foot. The average bound volume used 0.477 cubic feet of space, so each bound volume cost $\$ 0.596$ per year to maintain on the shelves.

The published work of these authors makes clear that the future availability of shelf space is a factor to consider in journal collection development decisions. The measurement and evaluation of the journal collection's consumption of shelf space can contribute to the decision to find electronic alternatives to traditional subscriptions. When combined with use data, shelf space consumption data also support storage, weeding, and shifting decisions. The combined shelf space and use data facilitate the identification of journals that might be moved to storage with minimal disruption of patrons' needs and maximum savings of valuable shelf space.

\section{BaCkground}

The College of Saint Rose is an independent, coeducational liberal arts college located in Albany, New York. It enrolls more than 1,700 full-time and 900 part-time students in 35 bachelor's degree programs and more than 1,300 students in 19 master's degree programs. The college's most heavily enrolled programs are in education, special education, the social sciences, business, liberal arts, and fine arts. Programs supported by scientific, medical, and technical journals are relatively small but are important components of the undergraduate curriculum. The college library subscribes to very few foreign language titles. The college's 45,000 square foot Neil Hellman Library houses over 195,000 bound volumes and maintains approximately 1,050 current periodical subscriptions. Detailed information about the college and the library can be found on the World Wide Web at www.strose.edu.

The primary goal of the library's serials collection development policy is to support the educational mission of the college, with a secondary goal of providing journals of general and cultural value to enhance students' personal growth. The policy states that collection development is carried out in accordance with the Library Bill of Rights, which proscribes censorship and ideological favoritism (American Library Association 1980). Support of faculty research is not an explicit goal of collection development. Journal selection has traditionally been driven by faculty requests for titles to support their programs. Since 1990 the library has enforced a general policy of no new net growth in the number of subscriptions in any academic area except to support new programs. The parsimonious addition of any new titles, combined with the usual trickle of ceased and canceled titles, has forestalled any major cancellation projects. But because subscription price increases and allocations for CD-ROM databases have significantly outstripped materials budget increases, the portion of funds left for books is rapidly shrinking to unacceptable levels. Consequently, I decided to conduct an empirical analysis of the journal collection to facilitate approaches to managing the looming materials budget crisis.

Collection Analysis Criteria

This journal collection analysis was based 
on measurements of journal use, journal subscription prices, and course enrollment. The primary goals of the analysis were to define and support criteria for determining the cost-effectiveness of the collection. The use data can also be used to support improved management of available shelf space. Cost-effectiveness criteria chosen for this study were the subscription prices per use of each journal, departmental expenditures for journals relative to academic departments' total annual course enrollment, the number of subscriptions in each department relative to annual course enrollment, and the rate of journal use in each department. The analysis based on these criteria has been helpful as an aid both to title-level decision-making within department journal budgets and to collection-level decision-making for the allocation of funds among department budgets. As options for providing journal literature through electronic means proliferate, careful analysis of the collection by individual title, by academic department, and by the collection as a whole is important for making informed decisions on possible augmentation or substitution of the print collection with electronic access.

\section{Data Collection Method}

During the fall of 1995, library staff measured journal shelf-space consumption. The total number of inches of shelf space occupied by each title was measured along with the shelf space taken by 1994 volumes. The library binds and permanently retains most journals, so 1994 was chosen to represent the space expected to be added by each title per year. No attempt was made to predict future changes in volume sizes, but changes in current year only holdings were accounted for. These data, along with each title's starting volume and year, were entered into a spreadsheet with an existing title list. These measurements indicated that, all things remaining equal, the "comfort zone capacity" of existing shelf space would be filled by 2002. Sapp and Suttle (1994) determined that $8^{\prime \prime}$ of empty space per $36^{\prime \prime}$ shelf was the "comfort zone" needed to allow for daily variations in space needs.

Given the library's space and budget constraints as well as the benefits of quantitative analysis explained above, I decided to conduct a use study in calendar year 1996. The library's last use study, conducted in 1981 for the sole purpose of identifying volumes to move to storage, used the method described by Shaw (1978). Lack of shelf space had again become a problem, and volumes were being moved to storage when room ran out on the shelves, with little regard for how often the titles were used. The sole purpose of the 1981 use study was to collect the data needed to rationalize the transfer of volumes to storage. The broader goal of the 1996 study was not only to identify volumes with very low use but also to provide the data needed to analyze the cost-effectiveness of each journal in the collection. Gathering the data needed to calculate subscription price per use was deemed important enough to expend the time and effort to measure all uses for a full calendar year. However, the study needed to be done within the existing budget and work schedule because no extra funds were available.

In consultation with colleagues and especially with the nonprofessional staff who would be directly involved in the project, I decided on a method of marking shelf labels each time a volume or issue was reshelved. Labels were created using word processing software, printed on standard $8 \frac{1}{2}-\mathrm{x}-11$-inch paper, and sliced to size. When inserted into the existing shelf label holders, the labels provided a marking space of $1 \frac{3}{4}$-inches on each side. Black fine-tip felt markers were obtained, signs were posted throughout the journal stacks asking patrons not to reshelve journals because a study was in progress, and instructions for shelvers were created and disseminated. Shelvers used the markers to put a dot to the left of the title for a volume dated before 1990; they put a dot to the right for a volume or issue dated 1990 or later. Cooperation by staff and student workers was good, and the method was readily understood. Bound volumes and individual issues were 
counted equally.

The most current issues of general interest titles are kept in a separate reading room and were not counted. This resulted in an undercount of some popular titles and reduced the incidence of individual issues counting the same as bound volumes. Indexes, newspapers, and serials not housed in the journals stacks were not included in the study. Of the library's 1,050 current periodical subscriptions, the study measured the use of 1,022 journals. Reshelved volumes were marked from January 17-December 15, 1996. Counts were taken and labels replaced after the spring 1996 and fall 1996 terms. Vandalized labels and labels crowded with dots were replaced as needed. The rate of vandalism was less than $1 \%$, but some data were lost for nine journals. In all but one case, the lost data were replaced by duplicating the count from the other semester. One journal suffered lost data for both semesters and was excluded from the study. Although the duplication of data for the nine journals from one semester to another reduced data integrity, noted similarities of recorded use between semesters for other titles made duplication more desirable than omission of the eight titles from the study.

There were four sets of reshelving counts: 1996 spring semester, pre-1990 volumes; 1996 spring semester, 1990-pre sent volumes; 1996 summer terms and fall semester, pre-1990 volumes; and 1996 summer terms and fall semester, 1990present volumes. The four sets of reshelving counts were added to the spreadsheet containing the shelf space data. The sum of uses for each title comprised the primary use data, but the four distinct sets were preserved in the spreadsheet.

Subscription prices paid for 1996 (in cluding price adjustments after initial vendor invoicing) for each of the 951 jour nals were entered into the spreadsheet. The College of Saint Rose allocates the materials budget among twenty-two departments. Each journal is coded to indicate the department's materials budget to which the subscription is allocated. These codes were included in the original title list and were carried over into the spread- sheet created for this study.

These data, when combined with subscription cost data, were sufficient to identify low-use titles and to calculate subscription price per use. But because the majority of the college's income comes from tuition, journal use figures are more meaningful in the context of the number of students served per subscription. To make such a calculation, I contacted the college registrar, who provided a printout of the enrollment for every undergraduate and graduate course conducted in calendar year 1996. Course enrollments were tabulated for each department, and the department totals were added to the spreadsheet. The total enrollment for courses by the college's 3,726 students for spring, summer, and fall 1996 was 29,155 . Because each subscription is coded by academic department, the number of students served can be measured by tallying each academic department's annual total course enrollment and comparing that to the number of subscriptions allocated to the department.

The library has a general category for journals not allocated to an academic department and a reference category for indexes and a few library journals. Journals for a department might receive significant use from students not enrolled in courses in that department, but there is no way to determine that from the data collected because the uses were counted with no attribution of users' course or department affiliation. However, estimated impact of cross-disciplinary use might be judged on a title-by-title basis.

\section{Data Analysis}

The spreadsheet created for this study included data for: journal title, academic department, subscription price, journal use, department course enrollment, and year subscription began. These data were used to calculate subscription price per use, subscription price per enrolled student, number of enrolled students per subscription in each department, and number of journal uses per enrolled student. These four calculations comprise the criteria for determining the cost-ef- 
TABLE 1

Subscription Price Per USE

\begin{tabular}{|c|c|c|c|c|}
\hline Department & Number of Subscriptions & Average Price & Total Uses & Price/Use \\
\hline Medical Technology & 9 & $\$ 317.73$ & 64 & $\$ 44.68$ \\
\hline Computer Science & 16 & 165.20 & 205 & 12.89 \\
\hline Biology & 43 & 270.92 & 1,083 & 10.76 \\
\hline Philosophy & 8 & 49.13 & 41 & 9.59 \\
\hline Public Communication & 49 & 78.03 & 470 & 8.14 \\
\hline Foreign Languages & 7 & 36.66 & 35 & 7.33 \\
\hline Music & 76 & 50.46 & 650 & 5.90 \\
\hline Psychology & 44 & 255.08 & 1,933 & 5.81 \\
\hline $\begin{array}{l}\text { History and Political } \\
\text { Science }\end{array}$ & 82 & 66.30 & 1,009 & 5.39 \\
\hline Business & 80 & 93.76 & 1,508 & 4.97 \\
\hline Sociology & 33 & 116.12 & 847 & 4,52 \\
\hline Religious Studies & 26 & 65.99 & 543 & 3.16 \\
\hline Physics & 14 & 86.35 & 403 & 3.00 \\
\hline Mathematics & 13 & 86.00 & 393 & 2.84 \\
\hline English & 116 & 49.29 & 2,023 & 2.83 \\
\hline Social Work & 6 & 115.60 & 368 & 1.88 \\
\hline Physical Education & 3 & 42.32 & 89 & 1.43 \\
\hline Education & 153 & 84.16 & 9,861 & 1.31 \\
\hline Special Education & 68 & 150.27 & 8,467 & 1.21 \\
\hline Art & 46 & 41.25 & 1,713 & 1.11 \\
\hline General & 71 & 47.41 & 3,835 & 0.88 \\
\hline Median & 43 & 84,16 & 650 & 4.52 \\
\hline
\end{tabular}

fectiveness of the journals in the collection. The four figures were calculated for every title, then sorted by department. Although the focus in this analysis was on the department level, the figures on individual titles will be instructive for yearly renewal decisions. All four criteria of cost-effectiveness are important to consider because each criterion provides a different but important perspective on the collection.

\section{Results}

Use data were collected for 1,022 journals. The total reshelving count was 35,433 . The median number of measured uses was 16. Records for titles that had ceased or had been canceled were extracted from the use counts and excluded from the cost efficiency analysis. If a journal had changed its title and was continued by a current title, the counts for these previous titles were added to the current title. With the adjustments for title changes and journals that had ceased or been canceled, 951 titles remained for analysis. Zero uses were recorded for 81 of these 951 journals (8.5\%).

Table 1 presents a summary of the calculated data on the use of journals and the subscription price per use in each department. Medians were calculated for each column as a standard for comparison. The data presented in table 1 show the relative expense of journals, the rate of use of the subscriptions, and the subscription price per use for each department. Table 1 is sorted by departments' average subscrip- 
TABLE 2

ENROLLMENT AND JOURNAL SUBSCRIPTIONS

\begin{tabular}{|c|c|c|c|c|c|}
\hline Department & $\begin{array}{l}\text { Department } \\
\text { Enrollment }\end{array}$ & $\begin{array}{c}\text { Department } \\
\text { Subscriptions }\end{array}$ & $\begin{array}{l}\text { Department } \\
\text { Enrollment/ } \\
\text { Department } \\
\text { Subscriptions }\end{array}$ & $\begin{array}{l}\text { Total } \\
\text { Uses }\end{array}$ & $\begin{array}{c}\text { Uses/ } \\
\text { Department } \\
\text { Enrollment }\end{array}$ \\
\hline Physical Education & 883 & 3 & 294,3 & 89 & 0.1 \\
\hline Psychology & 4,036 & 44 & 91.7 & 1,933 & 0.5 \\
\hline Computer Science & 1,460 & 16 & 91.3 & 205 & 0.1 \\
\hline Foreign Languages & 580 & 7 & 82.9 & 35 & 0.1 \\
\hline Special Education & 5,366 & 68 & 78.9 & 8,467 & 1.6 \\
\hline Mathematics & 768 & 13 & 59.1 & 393 & 0.5 \\
\hline Philosophy & 360 & 8 & 45.0 & 41 & 0.1 \\
\hline Social Work & 264 & 6 & 44,0 & 368 & 1.4 \\
\hline Business & 2,640 & 80 & 33.0 & 1,508 & 0.6 \\
\hline Art & 1,368 & 46 & 29.7 & 1,713 & 1.3 \\
\hline Education & 3,622 & 153 & 23.7 & 9,861 & 2.7 \\
\hline Religious Studies & 588 & 26 & 22.6 & 543 & 0.9 \\
\hline $\begin{array}{l}\text { Public } \\
\text { Communication }\end{array}$ & 1,087 & 49 & 22.2 & 470 & 0.4 \\
\hline Music & 1,606 & 76 & 21.1 & 650 & 0.4 \\
\hline Biology & 761 & 43 & 17.7 & 1,083 & 1.4 \\
\hline English & 1,950 & 116 & 16.8 & 2,023 & 1.0 \\
\hline $\begin{array}{l}\text { History \& Political } \\
\text { Science }\end{array}$ & 1,248 & 82 & 15.2 & 1,009 & 0.8 \\
\hline Sociology & 471 & 33 & 14.3 & 847 & 1.8 \\
\hline
\end{tabular}

tion price per use.

Table 2 shows journal subscriptions related to course enrollment for each department. Table 2 is sorted by department enrollment divided by department subscriptions, which indicates the enrollment rate per journal in each department. The departments in the top rows of table 2 are those with a relatively high enrollment rate per journal subscription. This table addresses the cost-effectiveness criteria of enrollment per subscription and number of uses per enrollment.

Table 3 also relates subscriptions and journal use with department enrollment. Table 3 displays the same data as table 2, but it is sorted by measured uses divided by department enrollment. The order of departments in table 3 highlights the rate of journal use relative to the number of students enrolled in each department's courses. The departments in the top rows of table 3 have greater rates of journal use relative to enrollment.

\section{DEPARTMENT ANALYSIS}

The data presented in tables 1,2 , and 3 for the four criteria of cost-effectiveness reinforced some of my perceptions of the collection but also revealed some surprises. Education and special education are the College of Saint Rose's most heavily enrolled programs, and reference service and library instruction provide extensive support for those programs. As expected, the subscription price per use in special education (\$1.21) is relatively low, enrollment per subscription (78.9) is well above the median, and the rate of use (1.6 uses per enrollment) is relatively high. These data suggest that the collec- 
TABLE 3

ENROLLMENT AND JOURNAL USE

\begin{tabular}{|c|c|c|c|c|c|}
\hline Department & $\begin{array}{l}\text { Department } \\
\text { Enrollment }\end{array}$ & $\begin{array}{c}\text { Department } \\
\text { Subscriptions }\end{array}$ & $\begin{array}{l}\text { Department } \\
\text { Enrollment' } \\
\text { Department } \\
\text { Subscriptions }\end{array}$ & $\begin{array}{l}\text { Total } \\
\text { Uses }\end{array}$ & $\begin{array}{c}\text { Uses/ } \\
\text { Department } \\
\text { Enrollment } \\
\end{array}$ \\
\hline Physics & 69 & 14 & 4.9 & 403 & 5.8 \\
\hline Education & 3,622 & 153 & 23.7 & 9,861 & 2.7 \\
\hline $\begin{array}{l}\text { Medical } \\
\text { Technology }\end{array}$ & 28 & 9 & 3.1 & 64 & 2.3 \\
\hline Sociology & 471 & 33 & 14.3 & 847 & 1.8 \\
\hline Special Education & 5,366 & 68 & 78.9 & 8,467 & 1.6 \\
\hline Biology & 761 & 43 & 17.7 & 1,083 & 1.4 \\
\hline Social Work & 264 & 6 & 44.0 & 368 & 1.4 \\
\hline Art & 1,368 & 46 & 29.7 & 1,713 & 1.3 \\
\hline English & 1,950 & 116 & 16.8 & 2,023 & 1.0 \\
\hline Religious Studies & 588 & 26 & 22.6 & 543 & 0.9 \\
\hline $\begin{array}{l}\text { History and } \\
\text { Political Science }\end{array}$ & 1,248 & 82 & 15.2 & 1,009 & 0.8 \\
\hline Business & 2,640 & 80 & 33.0 & 1,508 & 0.6 \\
\hline Mathematics & 768 & 13 & 59.1 & 393 & 0.5 \\
\hline Psychology & 4,036 & 44 & 91.7 & 1,933 & 0.5 \\
\hline $\begin{array}{l}\text { Public } \\
\text { Communication }\end{array}$ & 1,087 & 49 & 22.2 & 470 & 0.4 \\
\hline Music & 1,606 & 76 & 21.1 & 650 & 0.4 \\
\hline Computer Science & 1,460 & 16 & 91.3 & 205 & 0.1 \\
\hline Philosophy & 360 & 8 & 45.0 & 41 & 0.1 \\
\hline $\begin{array}{l}\text { Physical } \\
\text { Education }\end{array}$ & 883 & 3 & 294.3 & 89 & 0.1 \\
\hline $\begin{array}{l}\text { Foreign } \\
\text { Languages }\end{array}$ & 580 & 7 & 82.9 & 35 & 0.1 \\
\hline Median & 985 & 38 & 26.7 & 597 & 0.9 \\
\hline
\end{tabular}

tion in special education is cost-effective. The relatively low subscription price per use and relatively high rate of use in education was also expected.

The data partially reinforced, but also modified, my perception of the medical technology department. Its high subscription price per use (\$44.68) and low enrollment per subscription (3.1) make it stand out as a department that might have a collection that is not cost-effective. However, medical technology's relatively high rate of use ( 2.3 uses per enrollment) contradicted my impression that those journals are not used. This suggests that the inefficiency in medical technology is caused not by low use, but by high subscription prices and low enrollment, as evidenced by the $\$ 184.64$ subscription ex penditure per enrollment. Given this very high average price per use, alternative means of providing journal articles should be investigated even though the journals are used at a higher rate than was anticipated.

Use is, of course, affected by factors other than enrollment, such as available indexing and the nature of assignments given in each department's courses. The library currently does not have electronic 
citation databases specifically for computer science, biology, physics, or mathematics, and this might lower the rate of use in these areas. Faculty might avoid assignments that require literature searches, either because online indexes are not available or because they believe that too few journals are available in the library to support such assignments. Faculty teaching methods, especially the extent of library use required in class assignments, also make a difference. One professor in religious studies crafted assignments that required students to peruse the library's religious studies journals. The professor's emphasis on journal use, made in consultation with librarians, fairly clearly made a difference in the rate of use between his area (.92 uses per enrollment) and philosophy (.11 uses per enrollment). The price per use in religious studies was $\$ 3.19$; in philosophy it was $\$ 9.59$, despite higher average journal prices in religious studies. This experience with one professor in a small department demonstrates that promoting increased use might make a collection more cost-effective.

What constitutes acceptable cost-effectiveness, given the wide range of average subscription prices, department enrollments, and rates of use? As long as the college is committed to supporting an academic program, students should have access to journals in their field. In practice, the already high and rapidly rising subscription prices for journals limit the number of titles a library can hold, especially for departments with relatively few students. Subscription prices are an important factor in how access is provided. If access to journal literature can be provided via ILL or document delivery in a timely manner at less cost than subscriptions, it should be considered.

But the total costs of ILL or document delivery, including the time patrons would have to wait for delivery, must be weighed against the cost of subscriptions. In his analysis of the economics of access versus ownership, Kingma (1996) formulated a decision rule for determining when it is more economically efficient to have a journal on the shelf than it is to provide access to that journal by interlibrary loan. The decision rule is to subtract the fixed cost of a journal subscription from the subscription price, divide the result by the total uses of all subscription years derived from a one-year use study, and compare the resulting cost-per-use with the cost per acquisition by interlibrary loan. The Association of Research Libraries/Research Libraries Group cost estimate for obtaining an article on interlibrary loan was $\$ 18.62$ (Roche 1993). The SUNY study calculated the fixed cost of a journal subscription to be $\$ 62.96$ (Kingma 1996). If the College of Saint Rose assumed the same $\$ 62.96$ fixed cost per journal and $\$ 18.62$ per article interlibrary loan cost, 88 of our 951 journals $(9.25 \%)$ could theo retically be more efficiently provided by interlibrary loan than by owning the journals. From this evidence, the Neil Hellman Library's next steps will be to investigate the library's actual fixed costs and actual interlibrary lending cost, and determine the practical impact subscription cancellations would have on students, faculty, and library staff.

\section{Shelf Space Analysis}

This study has given me acceptably reliable data for making rational decisions for moving volumes to storage. The 81 zerouse journals constituted a list of prime targets for removal to storage. The shelf space consumption measurements taken in fall 1995 were used to calculate the amount of shelf space each title would take by the year 2000 , two years prior to predicted full capacity. The zero-use and shelf space data were applied in summer 1997 to move some journals to storage and to shift all the journals to allow for five years' growth for each title. The shifting of journals is intended to avoid for several years the need to move any more volumes to storage, but if the need unexpectedly arises, the use data will be available to inform the decision of which titles to move.

\section{Discussion and Application of Data}

The collection and analysis of shelf space, 
use, price, and enrollment data provide valuable insights regarding the journal collection. The label-marking method of measuring journal use was a logistical success, providing reliable data for reasonable effort and with very little disruption of work by patrons or library staff. The study created more work for the serials librarian and serials staff, but its design allowed label replacement and dot counting to be performed during the quieter times between semesters. The method requires that the person in charge of the study have access to a computer with word processing and spreadsheet software as well as a printer. Marking labels slows reshelving only marginally, but label replacement and dot counting take approximately ten to fifteen minutes per journal for the full process of initial labeling, midpoint relabeling, counting twice, and finally replacing shelf labels. Applying various analytical tools to the data expands to fill the time allotted to it.

Sources of error included people reshelving their own journals, people pulling off journals they didn't use, marking errors, counting errors, and data entry errors. These are sources of error with any use study based on reshelving counts. A nice overview of the advantages and disadvantages of the reshelving count method has been provided by Broadus (1985a).

The study's acceptably reliable use figures met the purpose of providing the data needed to evaluate the collection's costeffectiveness. The use figures combined with subscription prices yielded subscription-price-per-use data for each of the 951 journals. Reports were sent to each department head that described the study and provided a list of the department's journals ranked by subscription price per use. In the reports, it was explained that department recommendations for cancellations were welcome but not required. One fourth of the department heads responded, all with at least a few recommendations for cancellations. One department head mildly doubted the validity of the use study method (implying that students do their own reshelving), but still offered some titles for cancellation. A few depart- ment heads have indicated that they will use the data in a comprehensive review, and some have noted its value for accreditation self-assessments.

If continued subscription price inflation and restricted library materials budgets force a future cancellation project, faculty will have been given prior information about the cost and use of journals in their areas. The study's credibility and acceptance among faculty may have been improved by the absence of any immediate cancellation project. Sending reports that invited, but did not require, recommendations for cancellation avoided the hostile, negative reaction by faculty that others have reported (Millson-Martula 1988). Direct comparisons among departments were not distributed but are available to any faculty member on their request.

The use study reports sent to department heads represent a step in the ongoing journal collection development process. Based on the findings, cancellation of titles with the highest prices per use in each department, replacement of low-use titles with new titles, and reallocation of funds among departments should be considered. Other initiatives, such as working with faculty members to increase student use of journals, might also be in order. If it becomes necessary to calculate true cost-per-use-including binding, shelf space, and reshelving costs-the existing price and use data will make the task relatively easy. Future comparisons of print use before and after the availability in the library of full-text electronic journals should be informative. The library had no subscriptions to electronic journals in 1996, so this study makes a convenient pre-electronic baseline measurement of journal use.

\section{ACCREDITATION}

Individual academic departments seeking accreditation typically must meet library resource standards. These standards must be considered in journal collection development and can be an especially important concern for smaller departments. Continued renewal of accreditation for the college as a whole is a major driving 
force in college-wide planning. The College of Saint Rose, motivated by the standards of the accreditation organization, is now placing great emphasis on assessment. The Middle States Association Commission on Higher Education, the accreditation agency for the College of Saint Rose, emphasizes assessment of learning outcomes and promotes resourcebased learning. Executive Director Simmons (1992, 21) asks, "Do the grandiose statements in self-studies, periodic review reports, evaluation team reports, and other documents . . really mean that faculty and students are making maximum use of library and other information resources?" This use study provides a perspective on the learning process that should help the college's accreditation process in general and address the agency's interest in resourcebased learning in particular.

\section{Conclusions}

The data collection and analysis described here promises to be a valuable tool for improving the cost-effectiveness of the journal collection. The analysis elucidates each journal's price per use and each department's subscription expenditure per enrollment, enrollment per subscription, and rate of journal use per enrollment. Whether the value of this information will be realized depends on the collective wisdom and mutual cooperation of librarians and teaching faculty. The advent of fulltext electronic journals will make serials collection development more complex because librarians will not only have to decide what can be afforded out of the growing number of increasingly expensive journals, but they will also have to choose the medium through which journals will be provided. Quantitative title- and department-level analysis based on locally collected data provide anchor points for this decision-making process. Librarians could replicate this low cost study method to improve the foundations of their own journal collection development processes.

\section{WoRKs CITED}

American Library Association. 1980. Library Bill of Rights. Available online: http:// www.ala.org/work/freedom/br.html (April $4,1997)$.

Bensman, Stephen J. 1985. Journal collection development as a cumulative advantage process. College \& research libraries 46 : 13-29.

Broadus, Robert N. 1985a. The measurement of periodicals use. Serials review 11, no. 2: 57-61.

- 1985b. A proposed method for eliminating titles from periodical subscription lists. College d research libraries 46 : 30-35.

Eckman, Charles. 1988. Journal review in an environmental design library. Collection management 10, nos. 1/2: 69-84.

Edelman, Marla. 1994. Designing effective journal use studies. Serials librarian 24, nos. 3/4: 189-92.

Gossen, Eleanor A. and Suzanne Irving. 1995. Ownership versus access and low-use periodical titles. Library resources \& technical services 39: 43-52.

Joswick, Kathleen E and Jeanne Koekkoek Stierman. 1997. The core list mirage: A comparison of the journals frequently consulted by faculty and students. College $\mathrm{d}$ research libraries 58: 48-55.

Kingma, Bruce R. 1996. The economics of access versus ownership: The costs and benefits of access to scholarly articles via interlibrary loan and journal subscriptions. Binghamton, N.Y.: Haworth Press.

Metz, Paul. 1992. Thirteen steps to avoiding bad luck in a serials cancellation project. Joumal of academic librarianship 18, no. 2: 76-82.

Miller, Ruth H. and Marvin Guilfoyle. 1986. Computer assisted periodicals selection: Structuring the subjective. Serials librarian 10, no. 3: 9-22.

Millson-Martula, Christopher. 1988. Use studies and serials rationalization: A review. Serials librarian 15, nos. 1/2: 121-36.

Milne, Dorothy and Bill Tiffany. 1991. A costper-use method for evaluating the cost-effectiveness of serials: A detailed discussion of methodology. Serials review 17, no. 2: 7-19.

Naylor, Maiken. 1994. Comparative results of two current periodical use studies. Library resources d technical services 38: 373-88.

Roche, Marilyn M. 1993. ARL/RLG interlibrary loan cost study. Washington, D.C.; Association of Research Libraries.

Sapp, Gregg and George Suttle. 1994. A 


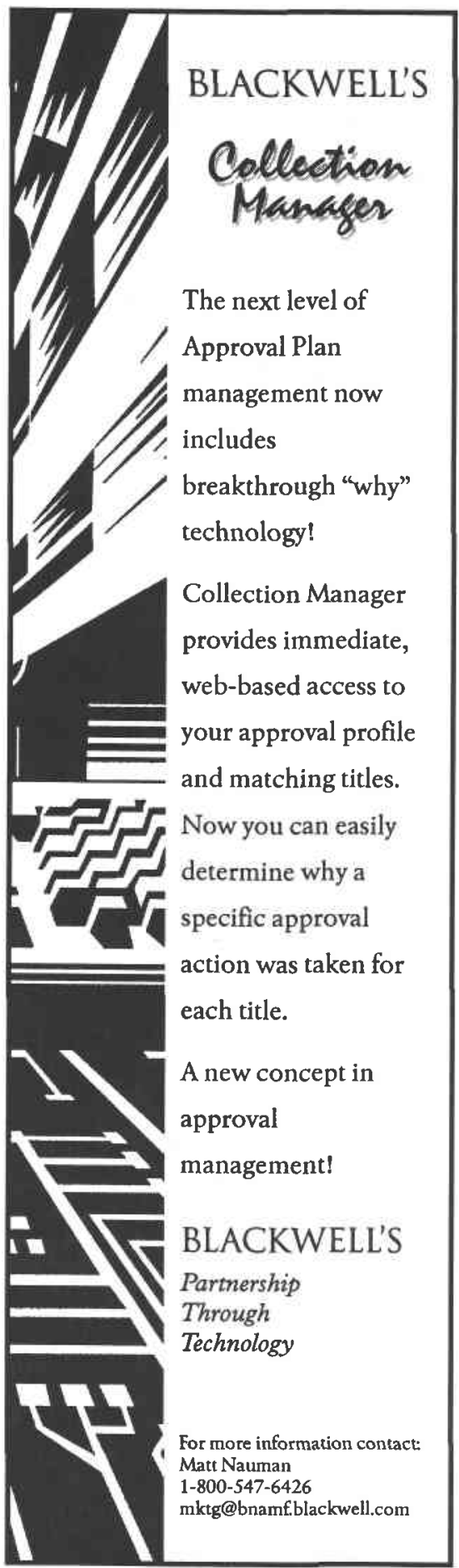

method for measuring collection expansion rates and shelf space capacities. Journal of academic librarianship 20, no, 4: $156-61$.

Shaw, W. M. 1978. A practical journal usage technique. College \& research libraries 38 : 479-84

Simmons, Howard L. 1992. Information literacy and accreditation: A Middle States Association perspective. New directions for higher education 78: 15-25.

Sylvia, Margaret and Marcella Lesher. 1995. What journals do psychology graduate students need? A citation analysis of thesis references. College \& research libraries 56: 313-18.

Young, Ian R. 1992. The use of a general periodicals bibliographic database transaction log as a serials collection management tool. Serials review 18, no. 4: 49-60. 